INTERNATIONAL JOURNAL OF MULTIDISCIPLINARY RESEARCh AND ANALySis

ISSN(print): 2643-9840, ISSN(online): 2643-9875

Volume 04 Issue 08 August 2021

DOI: 10.47191/ijmra/v4-i8-18, Impact Factor: 6.072

Page No.- 1193-1199

\title{
System Analysis and Marketing Strategy Grouper (Ephinephelus SPP) by Fishermen at Base Fish Landing (PPI) Oeba, Lama City District Kupang City
}

\author{
Syamsul Bahri ${ }^{1}$, Maria Emerensiana Jata ${ }^{2}$ \\ ${ }^{1,2}$ Fisheries Agribusiness Study Program, Faculty of Fisheries Muhammadiyah University of Kupang
}

ABSTRACT: This study aims (1) to determine the marketing system of grouper (Ephinephelus spp) at PPI Oeba, Kota Lama District, Kupang City. (2) To find out the marketing strategy of grouper (Ephinephelus spp) carried out by fishermen and grouper traders at PPI Oeba, Kota Lama District, Kupang City.

The method used in this study is a qualitative research method using SWOT analysis. The population in this study were fishermen, collectors, retailers at PPI Oeba, Kota Lama District, Kupang City.

The results of the research show (1) The grouper marketing system uses two marketing channels, namely marketing channel I where fishermen sell to consumer retailers and marketing channel II fishermen sell to consumer retailers. (2) The strategy applied to the PPI Oeba Landing Place, Fatubesi Sub-district, Kota Lama District is a Strength and Opportunity strategy. The Strength and Opportunity Strategy is an aggressive, growth-oriented strategy. Strategy is a very profitable strategy. The grouper marketing landing site has the power to take advantage of existing opportunities.

From the results of this study, it is recommended to expand the grouper marketing network so that grouper fish that have good quality can grow more rapidly and can be consumed by both the lower class, middle class, and upper middle class equally to consume grouper which has high nutritional value.

KEYWORDS: Marketing System, Marketing Strategy, Fishermen

\section{INTRODUCTION}

Grouper is one type of marine fish with important economic value found in Indonesian waters. Grouper has high nutritional value and can be cultivated commercially in several tropical countries. The delicious taste of the meat makes the grouper fish a high value in the world market. The high price of grouper is also due to its availability in nature starting to decrease. Grouper export destinations are Hong Kong, Taiwan, China, Japan, South Korea, Vietnam, Thailand, Philippines, USA, Australia, Singapore, Malaysia and France.

Grouper marketing is not only related to the aspect of grouper market structure, but also affects the income level of fishermen. Currently, the grouper marketing chain in Oeba, Kota Lama District, Kupang City still uses the marketing chain of local traders (gathering traders), inter-regional traders and exporters, almost the same model for fishermen in Indonesia. The problem that often arises in the grouper marketing chain is the share of value that can be obtained by fishermen from the catch depending on the weather conditions for grouper fishermen.

There is a tendency that the selling value of grouper at the fisherman level is very low while large profits are obtained by traders (collectors and exporters) besides that the weak position of fishermen in determining prices causes the proportion that fishermen get from their catch is smaller than that obtained by collectors and traders. so that it does not have an impact on the welfare of fishermen.

The sustainability of grouper fishery activities is strongly influenced by the value chain developed by the grouper fish business, from catching fish in the sea, distribution and marketing to local and foreign consumers. Business actors ranging from fishermen, collectors, retailers, wholesalers and exporters are the main constituents and actors of the grouper value chain.

The value chain provides a vehicle for identifying ways to develop differentiation through value development and distribution to each actor on each grouper commodity value at 


\section{System Analysis and Marketing Strategy Grouper (Ephinephelus SPP) by Fishermen at Base Fish Landing (PPI) Oeba, Lama City District Kupang City}

\section{LITERATURE REVIEW}

\section{Marketing Concept}

According to Fandy Tjiptono et al (2008) the marketing concept also emphasizes the integration between marketing functions (such as sales, advertising, customer service, product management, marketing research) and between departments (for example, the research and development department, the finance department, the human resources department, and the human resources department). production/operations). In other words, there is a need for alignment between external marketing (marketing aimed at parties outside the company) and internal marketing (the process of recruiting, selecting, training, and motivating employees so that they can serve customers satisfactorily).

\section{Marketing strategy}

PPI Oeba, Kota Lama District, Kupang City. From this basis, I am interested in conducting research on grouper marketing systems and strategies at PPI Oeba, Kota Lama District, Kupang City..

\section{RESEARCH METHOD}

This research has been carried out at PPI Oeba, Fatubesi Village, Kota Lama District, Kupang City. So the population in this study are fishermen, collectors and retailers totaling 53 people.

To simplify the processing of research data, in looking at this marketing strategy the author does not directly examine the entire population. Instead of using a portion of the population, namely "sampling using the formula Random Sampling is a sampling technique from members of the population that is carried out randomly without paying attention to the strata that exist in the population. The size of the sample taken is 6 respondents consisting of 2 fishermen, 2 collectors and 2 retailers.

\section{Analysis Data}

To see the marketing system, the data analysis carried out in this study used qualitative analysis methods.

To find out the marketing strategy of grouper in a SWOT analysis. In this study, one of the analytical tools used is the SWOT (Strength, Weakness, Opportunity, Threats) method of analysis.

The following are some of the steps in determining a business strategy using a SWOT analysis diagram, including the following:

1) Identification of indicators based on observations greatly determine the progress or decline of a business, based on Strengths, Weaknesses, Opportunities, and Threats in the SWOT matrix. The composition of these indicators is known as IFAS-Internal (Strengths and Weakness) and EFAS-External (Opportunity and Threats).

2) Determine the Weight and Rating for each indicator in IFAS (Internal Strategic Factors Analysis Summary) as follows :

- The following is the first weight (initial weight) with a measurable scale, in a measurable scale, namely: weight 1 (not important), weight 2 (less important), weight 3 (important) and weight 4 (very important). The weight that is written into the matrix is called the relative weight which is the result of dividing the initial weight by the total initial weight.

- Give weight to each factor, ranging from 1.0 (very important) to 0.0 (not important). The total weight must be 1.00 or 1 , and cannot be more than 1 .

- Provide a rating for each factor by giving a scale ranging from 4 (very good), 3 (good), 2 (good enough) and up to 1 (very bad) Based on the influence of these factors on the condition of the company.

- Multiply the weight by the rating, the result is a weighted score for each factor.

- Calculating the number of weighted scores $n$, this value is to map the company's position on the SWOT analysis diagram.

\section{RESULTS AND DISCUSSION}

\section{Marketing System at Grouper Landing Site}

The results showed that grouper landings in the Fatubesi village, Kota Lama District market grouper fish through two marketing channels, namely marketing channel I fishermen where fishermen directly sell to retailers and marketing channel II fishermen who sell grouper directly to collectors. From traders to collectors and retailers, PPI Oeba also sells fisherman to final consumers in restaurants in the city of Kupang, and exporters of grouper fish are shipped in frozen form with good quality fish to areas outside Kupang City. The price of grouper is still quite different/the price varies according to the type and size of grouper marketed.

The price of grouper marketed is still classified as varying in price according to the type of grouper marketed at the PPI Oeba market, Kota Lama District, Kupang City. The market behavior of PPI Oeba, Kupang City is a bargaining system between 


\section{System Analysis and Marketing Strategy Grouper (Ephinephelus SPP) by Fishermen at Base Fish Landing (PPI) Oeba, Lama City District Kupang City}

fishermen, collectors, retailers and consumers. Grouper is a good export commodity and has good quality and is more dominant for upper middle class consumers because it has high nutrition..

\section{Grouper Marketing Locations Grouper Shelters}

PPI Oeba markets grouper still in the Fatubesi Village area, Kota Lama District, Kupang and also markets it to other markets in Kupang City, namely:

1. Oebobo Market, Fatululi Village, Oebobo District, Kupang City.

2. Penfui Market, Penfui Village, Maulafa District, Kupang City.

3. Oeba Market, Fatubesi Village, Kota Lama District, Kupang City.

4. Pasar Kasih, Naikoten 1 Village, Kota Raja District, Kupang City

As is known, PPI Oeba markets various types of grouper. but the market that often markets Grouper in the grouper marketing process and is also a face-to-face market for PPI Oeba, while other markets are not permanent which only carry out the marketing or sales process when the fish are not sold out. But the fact is that grouper is always sold out at PPI Oeba. The researcher focuses on the fixed market owned by PPI Oeba.

PPI Oeba operates every day having a strategic and affordable place in the middle of Kupang city so that consumers don't take long to buy grouper.

\section{Grouper Marketing Strategy}

To find out the marketing strategy of grouper in a SWOT analysis. Before the researchers analyzed the SWOT strategy used by fishermen, collectors and retailers at PPI Oeba still had the usual strategies, such as selling grouper, but had not seen many opportunities. The fishermen are constrained by other fish so they are less competitive than other fish and are still comparing prices. It is recommended that fishermen's access and control capabilities in terms of knowledge and experience of catching fish be improved to see the opportunities for grouper fish which are in great demand by consumers. Having a SWOT Analysis tool is a strategy planning method used to evaluate strengths, weaknesses, opportunities, treats (threats) in a project or a business speculation (Osterwalder and Pigneur, 2010). According to Rangkuti (2006) the tool used to develop the company's strategic factors is the SWOT matrix. This matrix can clearly describe how the external opportunities and threats faced by the company can be adjusted to the strengths and weaknesses it has. This matrix can generate four sets of possible strategic alternatives.

Based on the analysis that has been done on the environment, both strengths and weaknesses. Opportunities and threats originating from grouper marketing landing sites, in this study several alternative strategies that can be used, can be explained as follows:

1. SO strategy is a strategy which is a combination of strengths and opportunities to take the existing opportunities. In this grouper marketing, SO strategies that can be applied include increasing the amount of grouper production from the previous production amount and expanding the marketing network considering that there is competition in the marketing of other fish at PPI Oeba, Fatubesi Village, Kota Lama District.

2. ST strategy is a strategy in using the company's strengths to overcome threats. In this grouper marketing, ST strategies that can be applied include expanding the marketing network and increasing marketing outside of the main activities, so that grouper sales can be sold quickly and the grouper marketing process is not hampered in markets that have competition with other fish marketing. Increasing business outside of main activities to prevent bad weather such as rain and wind, when the weather worsens the grouper fish production process and fishermen who do fishing are hampered from operating, so that for the time being fishermen and traders can shift their work to other businesses when the weather worsens so that these businesses running smoothly and unhindered.

3. This WO Strategy is a strategy that is applied based on the utilization of existing opportunities by minimizing existing weaknesses. In this grouper marketing, wO strategies that can be applied include expanding the marketing network so that it can help speed up the sales process and expedite the production process. Seeing that there are no similar competitors in Fatubesi Village, Kota Lama District.

4. This WT Strategy is a strategy based on activities that are defensive in nature and try to minimize existing weaknesses and avoid threats. In this grouper marketing, WT strategies that can be applied include expanding the marketing network. So that grouper marketing can be sold quickly, more smoothly and is not hampered by the market and competitors who sell other fish.

To support the SWOT matrix above in determining business strategy, it is also analyzed using SWOT diagrams, SWOT analysis diagrams include the following: 


\section{System Analysis and Marketing Strategy Grouper (Ephinephelus SPP) by Fishermen at Base Fish Landing (PPI) Oeba, Lama City District Kupang City}

1. Identify indicators based on Strengths, Weaknesses, Opportunities and Threats in the SWOT matrix.

The composition of these indicators is known as IFAS-Internal (Strengths and Weakness) and EFAS-External (Opportunity and Threats). The following is a table of indicators based on Strengths, Weaknesses, Opportunities and Treats in the following SWOT Matrix.

Table 1. Strengths, Weakness, Opportunity and Treaths Indicator in Matrixs SWOT

\begin{tabular}{|c|c|c|}
\hline SWOT & No & Indicator \\
\hline Strengts & $\begin{array}{l}1 \\
2 \\
3 \\
4\end{array}$ & $\begin{array}{l}\text { Have adequate fishing gear } \\
\text { Transportation/transportation facilities } \\
\text { Adequate fis } \\
\text { High human resources (HR) } \\
\text { Have a strategic place that can be reached by consumers } \\
\text { easily }\end{array}$ \\
\hline Weakness & $\begin{array}{l}1 \\
2 \\
3 \\
4\end{array}$ & $\begin{array}{l}\text { Depending on weather conditions } \\
\text { Lack of cleanliness of the market environment } \\
\text { The number of grouper sold has a limited product } \\
\text { Grouper price competition }\end{array}$ \\
\hline Opportunity & $\begin{array}{l}1 \\
2 \\
3 \\
4\end{array}$ & $\begin{array}{l}\text { For grouper fisherman has higher profit and income } \\
\text { Grouper is more dominant than other fish because it has } \\
\text { a high price } \\
\text { Grouper is a fishery commodity that has very attractive } \\
\text { export opportunities } \\
\text { Grouper is easily accessible to consumers who are at } \\
\text { home. }\end{array}$ \\
\hline Treats & $\begin{array}{l}1 \\
2 \\
3\end{array}$ & $\begin{array}{l}\text { Natural factor } \\
\text { High price of fish } \\
\text { Fish storage limitations }\end{array}$ \\
\hline
\end{tabular}

Matrix Source: marketing business owner and Researcher Processed

Determine the Weight and Rating for each indicator in IFAS (Internal Strategic Factors Analysis) as follows.

Strategic Factors Analysis Summary :

- Give weight first (initial weight) with a measurable scale, while the measured scales are: weight 1 (poor), weight 2 (below average), weight 3 (average), and weight 4 (good). The weight that is written into the matrix is called the relative weight which is the result of dividing the initial weight by the total initial weight.

- Give each factor a weight, ranging from 1.0 (Good) to 0.0 (average) to 0.0 . The total weight must be 1.00 or 1 , and cannot be more than 1.

- Calculating the rating for each factor by giving a scale starting from 4 (Good), 3 (average), 2 (below average) 1 (poor) based on the influence of these factors on the condition of the company.

- Multiply the weight by the rating, the result is a weighted score for each factor.

- Calculating the number of weighted scores, this value is to map the company's position on the SWOT analysis diagram. The following table determines the relative weights obtained from the initial weight division and the total initial weights.

Table 2 Determination of IFAS . Relative Weight

\begin{tabular}{|l|l|l|l|l|l|}
\hline IFAS & No & Indicator & Weight & Weight rank & Information \\
\hline Strengts & 1 & $\begin{array}{l}\text { Have adequate fishing gear } \\
\text { Have } \\
\text { transportation/transportation } \\
\text { facilities } \\
\text { Adequate fish } \\
\text { High human resources (hr) }\end{array}$ & 4 & 0,15 & Well \\
\hline
\end{tabular}


System Analysis and Marketing Strategy Grouper (Ephinephelus SPP) by Fishermen at Base Fish Landing (PPI) Oeba, Lama City District Kupang City

\begin{tabular}{|c|c|c|c|c|c|}
\hline IFAS & No & Indicator & Weight & Weight rank & Information \\
\hline & 4 & $\begin{array}{l}\text { Have a strategic place that can } \\
\text { be reached by consumers } \\
\text { easily }\end{array}$ & 4 & 0,15 & Well \\
\hline Weakness & $\begin{array}{l}1 \\
2 \\
3\end{array}$ & $\begin{array}{l}\text { Depending on weather } \\
\text { conditions } \\
\text { Lack of cleanliness of the } \\
\text { market environment } \\
\text { The number of grouper sold } \\
\text { has a limited product } \\
\text { Grouper price competition }\end{array}$ & $\begin{array}{l}2 \\
3 \\
3\end{array}$ & $\begin{array}{l}0,11 \\
0,11 \\
0,11 \\
0,15\end{array}$ & $\begin{array}{l}\text { Average } \\
\text { Average } \\
\text { Average } \\
\text { Well }\end{array}$ \\
\hline Amount & & & 27 & 1 & \\
\hline
\end{tabular}

Source: Marketing Strategy Business Owner and processed by Researchers

The next step is the analysis of internal strategic factors (Internal) Strategic Factors Analysis Summmary (EFAS) as shown in the table below as follows:

Table 3. Determination of EFAS. Relative Weight

\begin{tabular}{|l|l|l|l|l|l|}
\hline EFAS & No & Indicator & Weight & Weight rank & Information \\
\hline Opportunity & 1 & $\begin{array}{l}\text { For grouper fisherman has } \\
\text { higher profit and income } \\
\text { Grouper is more dominant } \\
\text { than other fish because it } \\
\text { has a high price } \\
\text { Grouper is a fishery } \\
\text { commodity that has very } \\
\text { attractive export } \\
\text { opportunities } \\
\text { Grouper is easily accessible } \\
\text { to consumers who are at } \\
\text { home. }\end{array}$ & 3 & 0,17 & Well \\
& 3 & $\begin{array}{l}\text { Natural Factor } \\
\text { High price of fish }\end{array}$ & 2 & 0,17 & Well \\
\hline threats & 1 & 2 & 3 & 0,17 & Well \\
\hline Amount & 3 & Fish storage limitations & 3 & 0.13 & Average \\
\hline
\end{tabular}

Source: Marketing Owner and Processed by Researchers

From the results of determining the relative weights of IFAS and EFAS then the internal and external matrices are made as follows:

Table 4. Internal Matrix of Factors Analysis Strategy Summary/ IFAS

\begin{tabular}{|l|l|l|l|l|l|}
\hline IFAS & No & Indicator & $\begin{array}{l}\text { weigh } \\
\mathrm{t}\end{array}$ & $\begin{array}{l}\text { Weight } \\
\text { rank }\end{array}$ & weight x rating \\
\hline power & 1 & $\begin{array}{l}\text { Have adequate fishing gear fish } \\
\text { Have adequate transportation } \\
\text { transportation/ } \\
\text { facilities Resource } \\
\text { High human (hr) Have a strategic } \\
\text { place that can be reached by } \\
\text { consumers easily }\end{array}$ & 3 & 0,15 & 0,59 \\
\cline { 2 - 6 } & 2 & 4 & 0,11 & 0,59 \\
\hline
\end{tabular}


System Analysis and Marketing Strategy Grouper (Ephinephelus SPP) by Fishermen at Base Fish Landing (PPI) Oeba, Lama City District Kupang City

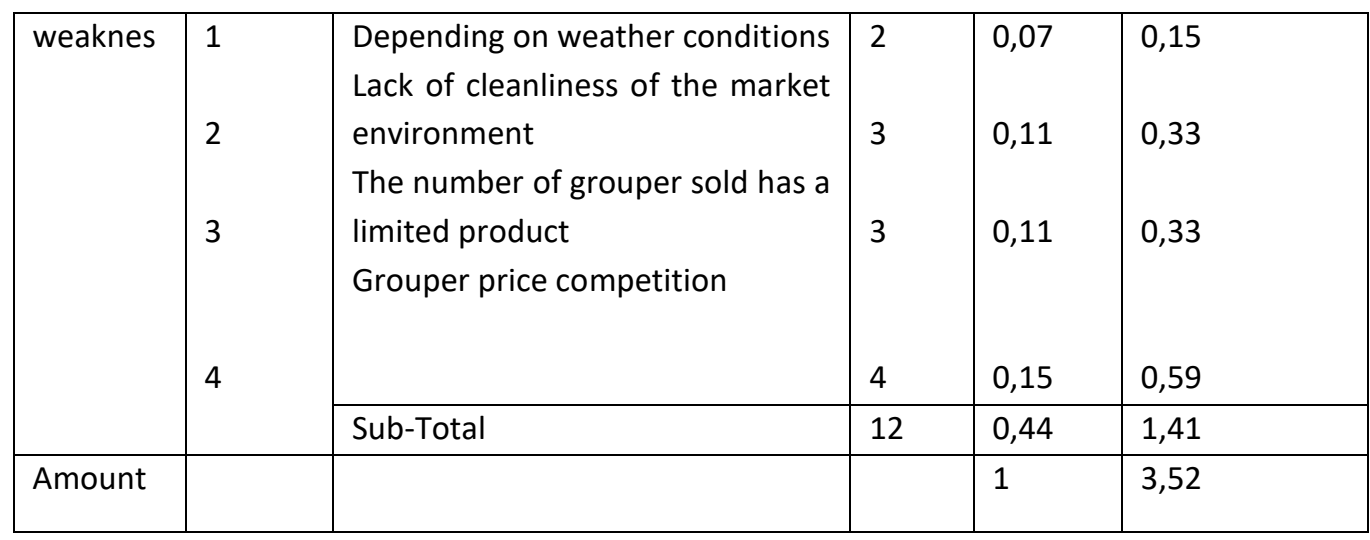

Source: Marketing Owner and Processed by Researchers

Based on the data from table 4 above, the value of strength is 2.11 which is higher than the value of weakness of 1.41 . So the value that can be used as the basis for policy is the value of strength.

Table 5. External Matrix of Factors Analysis Strategy Summary/EFAS

\begin{tabular}{|c|c|c|c|c|c|}
\hline EFAS & No & Indicator & weight & Weight rank & weight $x$ Rating \\
\hline \multirow[t]{5}{*}{ Opportunity } & 1 & $\begin{array}{l}\text { for grouper fisherman } \\
\text { has higher profit and } \\
\text { income }\end{array}$ & 4 & 0,17 & 0,70 \\
\hline & 2 & $\begin{array}{l}\text { Grouper is more } \\
\text { dominant than other } \\
\text { fish because it has a } \\
\text { high price }\end{array}$ & 4 & 0,17 & 0,70 \\
\hline & 3 & $\begin{array}{l}\text { Grouper is a fishery } \\
\text { commodity that has } \\
\text { very attractive export } \\
\text { opportunities }\end{array}$ & 4 & 0,17 & 0,70 \\
\hline & \multirow[t]{2}{*}{4} & $\begin{array}{l}\text { Grouper is easily } \\
\text { accessible to } \\
\text { consumers who are at } \\
\text { home }\end{array}$ & 3 & 0,13 & 0,39 \\
\hline & & Sub Total & 15 & 0,65 & 2,48 \\
\hline \multirow[t]{4}{*}{ Threat } & \multirow{4}{*}{$\begin{array}{l}1 \\
2 \\
3\end{array}$} & Natural Factor & 2 & 0,09 & 0,17 \\
\hline & & High price of fish & 3 & 0,13 & 0,39 \\
\hline & & $\begin{array}{ll}\text { Fish } & \text { storage } \\
\text { limitations } & \end{array}$ & 3 & 0,13 & 0,39 \\
\hline & & Sub Total & 8 & 0,35 & 0,96 \\
\hline \multicolumn{3}{|l|}{ Amount } & & 1 & 3,43 \\
\hline
\end{tabular}

Source: Marketing Owner and Processed by Researchers

Based on table 5 data, the opportunity value is 2.48 which is higher than the threat value is 0.96 . So the value that can be used as the basis for policy is the value of opportunity.

As shown in the SWOT analysis diagram above, it is clear that the strategy at the marketing landing site for grouper PPI Oeba in quadrant 1 is clearly seen, namely the SO strategy. The SO strategy is a very profitable strategy where the grouper marketing landing has the power so that it can take advantage of the opportunities that exist. The strategy that must be applied in this condition is to support an aggressive growth policy. 


\section{System Analysis and Marketing Strategy Grouper (Ephinephelus SPP) by Fishermen at Base Fish Landing (PPI) Oeba,}

Lama City District Kupang City

\section{CLOSING}

\section{Conclusion}

Based on the results of the research that has been done, the conclusions that can be drawn are as follows:

1. Grouper Marketing System where grouper fish land in Fatubesi sub-district, Kota Lama District, markets grouper through two marketing channels, namely marketing channel 1 where fishermen sell to retailers-consumers and marketing channel II, fishermen sell to traders-collectors-retailers-consumers.

2. The marketing strategy at the PPI Oeba grouper landing site in quadrant 1 is the SO strategy. SO Strategy is a very profitable Strategy. The grouper marketing landing site has the power to take advantage of the opportunities that exist.

\section{Suggestion}

Seeing the condition of grouper marketing at the Grouper Landing and Marketing Place in Fatubesi Village, Kelapa Lima District, Kupang City, there are several steps that must be taken to advance the grouper marketing:

1. Expanding the grouper marketing network so that grouper with good quality can grow even more rapidly and can be consumed by the lower class, middle class, and upper middle class equally to consume grouper which has high nutritional value.

2. The government, especially the Kupang City Government, should pay more attention to the lower middle class fishing communities, retail traders, and collector traders so that the grouper marketing business can survive and develop further.

\section{BIBLIOGRAPHY}

1) Amstrong, Gary \& Philip, Kotler (1996) Dasar-dasar Pemasaran. Jilid 1, Alih. Indonesia, Jakarta.

2) Amina, 2017. Analisis Rantai Nilai Pemasaran Ikan Kerapu (Ephinephelus spp) di Pulau Badi

3) Agus Purwanto, Erwan dan Dyah Rtih Sulistyastuti. 2011, Metode Penelitian Kuantitatif untuk Administrasi Publik dan Masalah-masalah Sosial Yogyakarta; Gava Media.

4) Bahasa Alexander Sindoro] dan Benyamin Molan, Prenhalindo, Jakarta

5) Dewi, Sherly Nurmala, 2015. Strategi Pemasaran. http;//ilmuekonomisherly. blogspot.co.id/2015/09.strategipemasaran-disusun-untuk.html.[Diakses tanggal 5 Februari 2020]

6) Fandy Tjiptono, 2008. Marketing New York Graw Hill Book Co.

7) Fandy Tjiptono, 2019. Strategi Pemasaran. Yogyakarta.

8) Kordi, 2001. Usaha Pembesaran Ikan Kerapu Dalam Tambak.Yogyakarta

9) Kompetitif.http;//andirmapaduwai.blogspot.co.id/2012/03/startegi divestasi strategi penetrasi,html. [Diakses tanggal 5 Februari 2020

10) Lubis Tampani Rias.2018. Analisis Pendapatan Dan Strategi Pemasaran Ikan Kerapu Tangkap Jurnal ilmu kelautan dan perikanan(Ephinepekus tauvina).

11) Lexi J. Moleong.2002. Meteodologi Penelitian Kualitatif Penerbit Remaja Rosdakarya Bandung.

12) Stanton, 2019 Pegertian Strategi Pemasaran Secara Umum Projasweb.com.

13) Sugiyono, 2008. Memahami Penelitian kualitatif. Bandung; Alfabeta.

14) Tjiptono, Fandy 2008. Strategi Pemasaran. Yogyakarta; ANDI. 